\title{
Evaluation of the Genotoxicity of Chlorpyrifos in Common Indus Valley Toad, Bufo stomaticus Using Alkaline Single-Cell Gel Electrophoresis (Comet) Assay
}

\author{
Muhammad Ismail1 ${ }^{*}$, Qaiser Mahmood Khan', Rahat Ali'1, Tayyaba Ali², Ameena Mobeen ${ }^{1}$ \\ ${ }^{1}$ Environmental Toxicology Laboratory, National Institute for Biotechnology and Genetic Engineering (NIBGE), \\ Faisalabad, Pakistan \\ ${ }^{2}$ Department of Zoology, Wildlife and Fisheries, Government College University Faisalabad, Faisalabad, \\ Pakistan \\ Email: ${ }^{\text {ismail nibge@yahoo.com }}$
}

Received 16 January 2014; revised 2 March 2014; accepted 19 March 2014

Copyright (C) 2014 by authors and Scientific Research Publishing Inc.

This work is licensed under the Creative Commons Attribution International License (CC BY). http://creativecommons.org/licenses/by/4.0/

(c) (i) Open Access

\begin{abstract}
Chlorpyrifos is a commonly used pesticide of organophosphate group, which causes toxicological effects in non-target organisms especially fish and frogs. In the present study, the genotoxicity of sublethal concentrations of chlorpyrifos was observed in the erythrocytes of common Indus valley toad, Bufo stomaticus, using the Alkaline Single-Cell Gel Electrophoresis (Comet) assay. In the first step, acute toxicity of chlorpyrifos was evaluated by exposing the tadpoles to high concentrations of the pesticide. The acute $\mathrm{LC}_{50}$ value of chlorpyrifos, calculated by Trimmed Spearman-Karber (TSK) in static bioassay, was found to be $930.0 \mu \mathrm{g} / \mathrm{L}$. On the basis of acute $\mathrm{LC}_{50}$ value, the tadpoles were exposed to three sublethal concentrations $(155,233$ and $465 \mu \mathrm{g} / \mathrm{L})$ of chlorpyrifos for $96 \mathrm{~h}$. Blood cells were collected at every $24 \mathrm{~h}$ interval and were subjected to the Alkaline Single-Cell Gel Electrophoresis assay. The observed DNA damage was concentration and time-dependent, and those levels of DNA damage in between the tested concentrations and times were significantly different $(p<0.05)$. The tadpoles exposed to different concentrations of chlorpyrifos also showed different morphological abnormalities. It was concluded that chlorpyrifos is a genotoxic pesticide causing DNA damage in Bufo stomaticus.
\end{abstract}

\section{Keywords}

Pesticide; Chlorpyrifos; Tadpoles; DNA Damage; Comet Assay

\footnotetext{
*Corresponding author.
} 


\section{Introduction}

Pesticides are widely used in agricultural areas to improve the crop yield, but the indiscriminate use of these chemicals in the environment causes toxicity to the non-target organisms. These pesticides tend to reach into the adjacent small water bodies (e.g., ponds, creeks, and drainage ditches) and may exhibit toxicity and genotoxicity to aquatic organisms.

Chlorpyrifos [O,O-diethyl O-(3,5,6-trichloro-2-pyridyl) phosphorothioate] is a wide-ranging organophosphate insecticide used to control the agricultural and household pests [1]. It inhibits the acetylcholine esterase (AChE) enzyme and affects the nervous system of the aquatic organisms [2]. The insecticides are transported to the freshwater water bodies through run-off and storm water [3] [4] and severely affect the aquatic biodiversity of that area. These chemicals not only have negative impacts on the physiology of organisms but also interact with their DNA [5].

Amphibians are found in the aquatic, wetlands and agricultural ecosystems and are very important natural enemies of many agricultural insect pests. As the amphibians in their larval stages live in aquatic environment, they are regarded as bio-indicators [6] [7] and are widely used as test specimens in the assessment of toxic effects of pesticides on aquatic ecosystem [8]. A number of studies have demonstrated that the amphibians are sensitive and suitable organisms for the assessment of genotoxicity of pollutants [5] [9] [10].

Chlorpyrifos has already been found genotoxic in the root meristematic cells of Crepis capillaries [11]. It has been reported genotoxic in gill cells and lymphocytes of freshwater fish Channa punctatus (Bloch) [12] and in leucocytes of Swiss albino mice [13]. Genotoxicity of chlorpyrifos has also been evaluated in liver cells and erythrocytes of Chinese toad (Bufo bufo gargarizans) tadpoles [14].

Among different techniques used for the evaluation of DNA strand breakage, we selected to employ alkaline single-cell gel electrophoresis/comet assay to quantify DNA damage in the erythrocytes of Bufo stomaticus exposed to sublethal concentrations of chlorpyrifos. Comet assay has many advantages over other cytogenetic assays like micronucleus test, chromosomal aberration test and sister chromatid exchanges to detect DNA damage. Comet assay permits the visualization of DNA damage at an individual cell level [15]; relatively few cells are required and any cell having a nucleus can be used in this assay. The comet assay is very sensitive (detecting 1 strand break in $1 \times 10^{10}$ Da of DNA) [16] and shows a clear dose dependent response. It is less expensive and less time-consuming than other biomonitoring assays [5].

There was no study on the toxicity and genotoxicity of chlorpyrifos in Bufo stomaticus. The present study was conducted to investigate the acute toxicity and genotoxicity of chlorpyrifos in Bufo stomaticus in a static bioassay. This study may also direct to reinforce the fact of the effectiveness of the Comet assay as a sensitive biomarker of DNA damage in the erythrocytes of Bufo stomaticus.

\section{Materials and Methods}

\subsection{Chemicals}

Normal melting point (NMP) agarose was purchased from Invitrogen Life Technologies Ltd. (Paisley, UK). Low melting point (LMP) agarose was obtained from Promega Corporation (Madison, USA). Methyl methanesulfonate (MMS) and Ethidium bromide (EtBr) were supplied by Sigma-Aldrich, (St. Louis, MO, USA). Triton X-100 was obtained from Applichem Gmbh (Darmstodt, Germany). Phosphate buffered saline (PBS) was purchased from Invitrogen (Carlsbad, USA). Ethylenediamine tetraacetic acid (EDTA) disodium salt was obtained from GIBCO Life technologies Inc., (New York, USA). Dimethyl sulphoxide (DMSO) was supplied by Labscan Asia Co Ltd., (Bangkok, Thailand). Trizma base, $\mathrm{NaOH}, \mathrm{HCl}, \mathrm{NaCl}, \mathrm{MgSO}_{4} \cdot 7 \mathrm{H}_{2} \mathrm{O}, \mathrm{K}_{2} \mathrm{HPO}_{4}$, and all other chemicals used were of analytical grade. Commercial formulation of chlorpyrifos product ( $40 \%$ EC), named as "Chlorpyrifos" (manufactured by M/s. K \& N Efthymiadis, Greece), was purchased from the local market. It was observed that the chlorpyrifos of this grade is mostly employed in the fields.

\subsection{Experimental Specimen}

Tadpoles of Bufo stomaticus were obtained from NIBGE Faisalabad fields and shifted to the glass aquaria. These specimens were acclimatized for 15 days prior to the pesticide exposure with a 16:8 h (light:dark) photoperiod. The specimens were fed with boiled lettuce ad libitum, and feeding was stopped $24 \mathrm{~h}$ prior to the pesticide exposure till the end of the experiment. 


\subsection{Determination of Acute Toxic and Sublethal Concentrations}

Stock solution of the insecticide was prepared by dissolving chlorpyrifos in acetone. Five working chlorpyrifos concentrations $(0.4,0.8,1.2,1.6$ and $2.0 \mathrm{mg} / \mathrm{L}$ ) were prepared in the solvent (acetone) from the stock solution. To determine the acute $\mathrm{LC}_{50}$ value of chlorpyrifos, static bioassay was employed. Six groups of tadpoles, each containing 10 individuals, were selected at random and placed in the aquaria. Glass aquaria (with dimensions of $30 \mathrm{~cm}$ depth, $30 \mathrm{~cm}$ width and $45 \mathrm{~cm}$ length), with the capacity of about $40 \mathrm{~L}$ was filled with $15 \mathrm{~L}$ of water. The temperature of the water was regulated at $26^{\circ} \mathrm{C} \pm 1^{\circ} \mathrm{C}$. The electric conductivity and the $\mathrm{pH}$ of water were 2.62 $2.76 \mathrm{mS}$ and $8.77-9.29$, respectively. The above mentioned concentrations were added to different aquaria containing specimens, keeping one as solvent control receiving no pesticide but maximum acetone that any dosing solution contain. Acute toxicity assay was performed following the guidelines of Organization for Economic Co-operation and Development (OECD) for testing of chemicals [17].

Acute $\mathrm{LC}_{50}(96 \mathrm{~h})$ value of chlorpyrifos for tadpoles was calculated as $930.0 \mu \mathrm{g} / \mathrm{L}$ (95\% Confident limits:

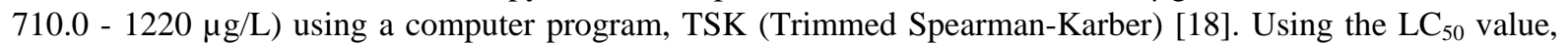
three nominal sub-lethal concentrations viz., sub-lethal I (SL-I, $1 / 2^{\text {nd }}$ of $\mathrm{LC}_{50}=465 \mu \mathrm{g} / \mathrm{L}$ ), sub-lethal II (SL-II, $1 / 4^{\text {th }}$ of $\mathrm{LC}_{50}=233 \mu \mathrm{g} / \mathrm{L}$ ) and sub-lethal III (SL-III, $1 / 6^{\text {th }}$ of $\mathrm{LC}_{50}=155 \mu \mathrm{g} / \mathrm{L}$ ) were prepared.

\subsection{In Vivo Sublethal Exposure Experiment}

The tadpole were exposed to three above mentioned sublethal concentrations of chlorpyrifos in a static bioassay system for $96 \mathrm{~h}$ with a 16:8 h (light:dark) photoperiod. Blood samples were obtained at the intervals of 24, 48, 72 and $96 \mathrm{~h}$ from the two tadpoles per concentration per interval. Dechlorinated tap water and methyl methanesulfonate (MMS) (5 mg/L) were used as negative and positive controls, respectively.

Physico-chemical properties of water $(\mathrm{pH}$, temperature, dissolved oxygen, electrical conductivity and total hardness) were analyzed at the start and at the completion of experiment.

\subsection{Alkaline Single Cell Gel Electrophoresis (SCGE)}

The alkaline single cell gel electrophoresis (SCGE)/Comet assay was performed using the procedure of Singh et al. [19] with slight modifications of Ralph et al. [10]. The tadpoles were decapitated and placed in $1 \mathrm{ml}$ chilled phosphate buffered saline (PBS, Calcium and Magnesium-free) for $5 \mathrm{~min}$. All the specimens were treated separately. The erythrocytes of the tadpoles were selected for DNA damage as these cells are much more numerous in the circulatory system and are nucleated in amphibians. The viability of the cells was assessed using the Trypan blue exclusion method [20]. Cell samples exhibiting cell viability more than $84 \%$ were further processed for comet assay.

About $20 \mu \mathrm{l}$ of the cell suspension was mixed with $80 \mu \mathrm{l}$ of $0.5 \%$ LMP agarose and pipetted on a slide already coated with $200 \mu \mathrm{l}$ of $0.9 \%$ NMP agarose. After solidification, slides were coated with a third layer of $100 \mu \mathrm{l}$ of $0.5 \%$ LMP agarose and covered with cover slips. The slides were placed at $4^{\circ} \mathrm{C}$ for $20 \mathrm{~min}$ to allow for complete polymerization of agarose. After the polymerization of the agarose, the cover slips were removed and the slides were immersed in freshly prepared cold lysing solution $(2.5 \mathrm{M} \mathrm{NaCl}, 100 \mathrm{mM} \mathrm{Na} 2$ EDTA, $10 \mathrm{mM}$ Tris, $10 \%$ DMSO and $1 \%$ Triton $\mathrm{X}-100, \mathrm{pH} 10.0$ ) for $2 \mathrm{~h}$ at $4^{\circ} \mathrm{C}$. Then the slides were placed in fresh cold alkaline electrophoresis buffer (300 mM NaOH, $1 \mathrm{mM} \mathrm{Na} \mathrm{NaDTA}_{2} \mathrm{pH}>13$ ) in a horizontal gel electrophoresis unit for 25 $\min$ at $44^{\circ} \mathrm{C}$, allowing for DNA unwinding and salt equilibrium. Electrophoresis was carried out in the same solution at $25 \mathrm{~V}(\sim 0.73 \mathrm{~V} / \mathrm{cm}), 300 \mathrm{~mA}$ for $25 \mathrm{~min}$. The slides were then neutralized with neutralizing buffer $(0.4 \mathrm{M}$ Tris, pH 7.5) for 5 min to remove excess alkali. This step was repeated three times. Then the slides were dried and stained with $20 \mu \mathrm{l}$ of ethidium bromide $(20 \mu \mathrm{g} / \mathrm{ml})$. Slides were observed under an epifluorescent microscope (Labomed Lx400, Labo America, Inc., USA) equipped with an excitation filter 515 - $560 \mathrm{~nm}$ and emission filter $590 \mathrm{~nm}$. Total 100 individual cells were observed per tadpole per concentration (50 cells per slide). The cells with no DNA damage have nucleoids, whereas the cells with DNA damage have comet-like appearance. The cells having DNA damage with no head or a dispersed head were regarded as apoptotic cells and were not considered for the analysis. The length of the migrated DNA in the Comet tail was measured using an ocular micrometer [21]. DNA damage was measured at individual cell level with the help of the following formula:

Comet tail length $(\mu \mathrm{m})=$ total comet length - head diameter 


\subsection{Statistical Analysis}

Statistical analysis of the data was carried using Statistix 8.1 computer software. Analysis of variance (ANOVA) was employed to compare the mean differences in the tail length between different concentrations within time durations and between time durations within concentrations. A $p$ value less than 0.05 was considered as statistically significant.

\section{Results}

Physico-chemical characteristics of the water used in the experiments recorded, as $\mathrm{pH}$ : $8.2 \pm 0.1$; temperature: $26^{\circ} \mathrm{C} \pm 1{ }^{\circ} \mathrm{C}$; dissolved oxygen: $8.6 \pm 0.2$; electrical conductivity: $2.65-2.75 \mathrm{mS} / \mathrm{m}$; total hardness: 86 - 96 as $\mathrm{mg}$ $\mathrm{CaCO}_{3} / \mathrm{L}$, were according to USEPA specifications [22]. Acute LC50 values (with 95\% confidence limits) of chlorpyrifos to Bufo stomaticus at $24 \mathrm{~h}, 48 \mathrm{~h}, 72 \mathrm{~h}$ and $96 \mathrm{~h}$ were $1070 \mu \mathrm{g} / \mathrm{L}$ (820 - 1410), $1040 \mu \mathrm{g} / \mathrm{L}$ (800 - 1360), $970 \mu \mathrm{g} / \mathrm{L}(740$ - 1280) and $930 \mu \mathrm{g} / \mathrm{L}(710$ - 1220) respectively. In addition to the lethal effects of chlorpyrifos, the pesticide also has negative effects on the morphology of the tadpoles during the experimental period. These morphological abnormalities include tail deformities, fins shrunken and head edema.

Erythrocytes of the Bufo stomaticus tadpoles were used to assess the genotoxicity of chlorpyrifos using the comet assay. The tail length $(\mu \mathrm{m})$ of the comet was measured as the degree of DNA damage. Significantly higher $(\mathrm{p}<0.05)$ levels of DNA damage were observed in the erythrocytes of tadpoles exposed to all the three sublethal concentrations of chlorpyrifos relative to the negative control (Table 1). It was found that the increase in DNA damage was significantly concentration dependent. DNA damage observed at the lowest concentration of chlorpyrifos $(155 \mu \mathrm{g} / \mathrm{L})$ was $53.61 \pm 5.71 \mu \mathrm{m}$, significantly increased to $71.22 \pm 5.21 \mu \mathrm{m}$ at the highest concentration $(465 \mu \mathrm{g} / \mathrm{L})$ at $24 \mathrm{~h}$ exposure (Table 1). Same trend was observed at other three exposures time durations. It was also found that the increase in DNA damage was exposure time dependent. At the lowest sublethal concentration of chlorpyrifos $(155 \mu \mathrm{g} / \mathrm{L})$, there was no significant increase in DNA damage was observed at all exposure time intervals. Whereas, at the sublethal concentration $233 \mu \mathrm{g} / \mathrm{L}$, DNA damage was significantly $(p<0.05)$ increased from $57.88 \pm 6.38 \mu \mathrm{m}$ at $24 \mathrm{~h}$ to $74.13 \pm 8.67 \mu \mathrm{m}$ at $96 \mathrm{~h}$. The same trend in significant increase in DNA damage was observed at the highest concentration of chlorpyrifos ( $465 \mu \mathrm{g} / \mathrm{L})$ from $24 \mathrm{~h}$ to $96 \mathrm{~h}$ time intervals.

\section{Discussion}

Tadpoles are useful experimental organisms for environmental bio-monitoring studies due to their availability in sufficient numbers, ease to collect, confinement to water bodies and direct exposure to contaminants in water and vegetation [23]. In this study, the acute toxicity and genotoxicity of chlorpyrifos were evaluated in Bufo stomaticus tadpoles. The acute $\mathrm{LC}_{50}(96 \mathrm{~h})$ value of chlorpyrifos in Bufo stomaticus was calculated as 930.0 $\mu \mathrm{g} / \mathrm{L}(0.93 \mathrm{mg} / \mathrm{L})(95 \%$ confident limits: $710.0-1220 \mu \mathrm{g} / \mathrm{L})$. The results showed that chlorpyrifos is moderately toxic to Bufo stomaticus. The $\mathrm{LC}_{50}$ value of chlorpyrifos in Chinese toad (Xenopus laevis) tadpoles was 0.56 $\mathrm{mg} / \mathrm{L}$ and it was found that the tadpoles exposed to the insecticide during metamorphs were more sensitive than those exposed at pre-metamorphs [24]. In another study, the acute $\mathrm{LC}_{50}(48 \mathrm{~h})$ value of chlorpyrifos to Rana limnocharis was found to be $2.40 \mathrm{mg} / \mathrm{L}$ [25].

Table 1. Mean comet tail length $(\mu \mathrm{m}), \pm \mathrm{SD}$, of erythrocytes of Bufo stomaticus exposed to different concentrations of chlorpyrifos at different time intervals.

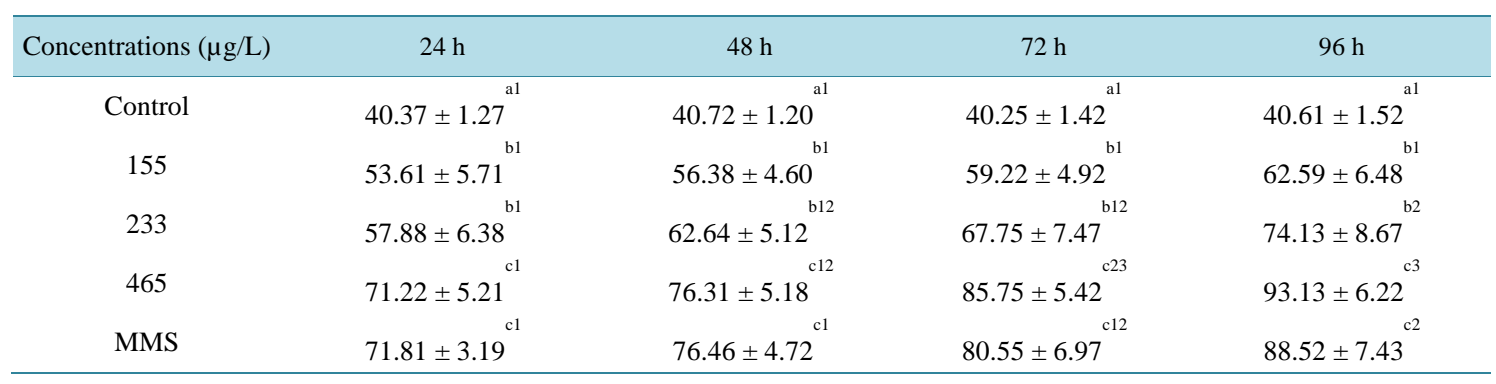

Note: values with different alphabet superscripts differ significantly $(p<0.05)$ between concentrations within duration. The values with different numeric superscripts differ significantly $(p<0.05)$ between durations within concentration. 
The alkaline single-cell gel electrophoresis/comet assay is a commonly known biomarker of genotoxicity in organisms exposed to environmental genotoxic pollutants and the greater the number of comets is associated with the serious health consequences in the organisms [26]-[28]. Chlorpyrifos was not found to be genotoxic in any of these assays (Ames test, rat lymphocyte chromosomal aberration test, CHO/HGPRT assay, mouse bone marrow Micronucleus assay, cytogenetic abnormalities) [29]. But later on, it was reported that chlorpyrifos induce in-vivo genotoxicity in leucocytes of Swiss albino mice using Comet assay [13]. Chlorpyrifos has also been observed genotoxic in root meristematic cells of Crepis capillaries [11], and in lymphocytes and gill cells of freshwater fish Channa punctatus (Bloch) [12].

A number of studies have reported the genotoxicity of pesticides in amphibians [14] [30]-[33]. Chlorpyrifos induced the genotoxicity in erythrocytes and liver cells of Chinese toad (Bufo gargarizans) when the tadpoles were exposed to the sublethal concentrations of chlorpyrifos $(80.0 \mu \mathrm{g} / \mathrm{L}, 160.0 \mu \mathrm{g} / \mathrm{L}, 320.0 \mu \mathrm{g} / \mathrm{L}, 640.0 \mu \mathrm{g} / \mathrm{L})$ [33]. A concentration-dependent increase in DNA damage was observed in the erythrocytes and liver cells of Chinese toad. Our results also showed an increase in DNA damage (tail length) in erythrocytes of Bufo stomaticus exposed to sublethal concentrations of chlorpyrifos and this increase in DNA damage was concentration and time-dependent (Table 1).

In this study, chlorpyrifos induced a significantly $(p<0.05)$ higher DNA damage in the erythrocytes of Bufo stomaticus tadpoles as compared to negative control, depicting the genotoxic nature of chlorpyrifos to amphibians. A significantly concentration-dependent increase in DNA damage was observed at all the exposure concentrations of chlorpyrifos. The lower two sublethal concentrations of chlorpyrifos (155 and $233 \mu \mathrm{g} / \mathrm{L}$ ) showed significant DNA damages as compared to negative control, but did not show any significantly $(p<0.05)$ different results with respect to each other. The highest concentration $(465 \mu \mathrm{g} / \mathrm{L})$ induced significantly $(p<0.05)$ higher DNA damages as compared to negative control and other two chlorpyrifos concentrations at all the exposure time durations (Table 1). Our observations are in accordance with the previous studies in which different pesticides induced concentration-dependent increase in DNA damages in different amphibian species [14] [30] [33].

Induction in DNA damages in the erythrocytes of Bufo stomaticus tadpoles was mostly time-dependent. Observed DNA damages were significantly $(p<0.05)$ increased at most of the time durations in the higher two chlorpyrifos concentrations (Table 1). Same-time dependent increase in DNA damage was found in Xenopus laevis and Pleurodeles waltl tadpoles when exposed to Captan (a fungicide) [32].

\section{Acknowledgements}

The authors are thankful to the Higher Education Commission (HEC) Islamabad, Pakistan for providing the funds to conduct this study.

\section{References}

[1] Lemus, R. and Abdelghani, A. (2000) Chlorpyrifos: An Unwelcome Pesticide in Our Homes. Reviews on Environmental Health, 15, 421-433. http://dx.doi.org/10.1515/REVEH.2000.15.4.421

[2] Sun, F. and Chen, H.S. (2008) Monitoring of Pesticide Chlorpyrifos Residue in Farmed Fish: Investigation of Possible Sources. Chemosphere, 71, 1866-1869. http://dx.doi.org/10.1016/j.chemosphere.2008.01.034

[3] Brady, J., Wallender, W., Werner, I., Fard, B.M., Zalom, F., Oliver, M., Wilson, B., Mata, M., Henderson, J. and Deanovic, L. (2006) Pesticide Runoff from Orchard Floors in Davis, California, USA: A Comparative Analysis of Diazinon and Esfenvalerate. Agriculture, Ecosystems and Environment, 115, 56-68. http://dx.doi.org/10.1016/j.agee.2005.12.009

[4] Weston, D., Holmes, R., You, J. and Lydy, M. (2005) Aquatic Toxicity Due to Residential Use of Pyrethroid Insecticides. Environmental Science and Technology, 39, 9778-9784. http://dx.doi.org/10.1021/es0506354

[5] Rajaguru, P., Kalpana, R., Hema, A., Suba, S., Baskarasethupathi, B., Kumar, P. and Kalaiselvi, K. (2001) Genotoxicity of Some Sulfur Dyes on Tadpoles (Rana hexadactyla) Measured Using the Comet Assay. Environmental and Molecular Mutagenesis, 38, 316-322. http://dx.doi.org/10.1002/em.10027

[6] Pollet, I. and Leah, I.B.-Y. (2000) Amphibians as Indicators of Wetland Quality in Wetlands Formed from Oil Sands Effluent. Environmental Toxicology and Chemistry, 19, 2589-2597. http://dx.doi.org/10.1002/etc.5620191027

[7] Schuytema, G. and Nebeker, A. (1999) Effects of Ammonium Nitrate, Sodium Nitrate, and Urea on Red-Legged Frogs, Pacific Treefrogs, and African Clawed Frogs. Bulletin of Environmental Contamination and Toxicology, 63, 357-364. 
http://dx.doi.org/10.1007/s001289900988

[8] Sundaram, K. (1995) Distribution, Persistence, and Fate of Mexacarbate in the Aquatic Environment of a Mixed-Wood Boreal Forest. Journal of Environmental Science \& Health Part B, 30, 651-683. http://dx.doi.org/10.1080/03601239509372959

[9] Le Curieux, F., Marzin, D. and Erb, F.O. (1992) Genotoxic Activity of Three Carcinogens in Peripheral Blood Erythrocytes of the Newt Pleurodeles waltl. Mutation Research MUREAV, 283.

[10] Ralph, S., Petras, M., Pandrangi, R. and Vrzoc, M. (1996) Alkaline Single-Cell Gel (Comet) Assay and Genotoxicity Monitoring Using Two Species of Tadpoles. Environmental and Molecular Mutagenesis, 28, 112-120. http://dx.doi.org/10.1002/(SICI)1098-2280(1996)28:2<112::AID-EM7>3.0.CO;2-H

[11] Dimitrov, B. and Gadeva, P. (1997) Genotoxicity Studies on the Insecticide Dursban in Root Meristem Cells of Crepis capillaris L. Environmental Experimental Botany, 37, 199-209. http://dx.doi.org/10.1016/S0098-8472(96)01042-8

[12] Ali, D., Nagpure, N., Kumar, S., Kumar, R. and Kushwaha, B. (2008) Genotoxicity Assessment of Acute Exposure of Chlorpyrifos to Freshwater Fish Channa punctatus (Bloch) Using Micronucleus Assay and Alkaline Single-Cell Gel Electrophoresis. Chemosphere, 71, 1823-1831. http://dx.doi.org/10.1016/j.chemosphere.2008.02.007

[13] Rahman, M.F., Mahboob, M., Danadevi, K., Saleha Banu, B. and Grover, P. (2002) Assessment of Genotoxic Effects of Chloropyriphos and Acephate by the Comet Assay in Mice Leucocytes. Mutation Research, 516, 139-147. http://dx.doi.org/10.1016/S1383-5718(02)00033-5

[14] Yin, X.H., Zhu, G.N., Li, X.B. and Liu, S.Y. (2009) Genotoxicity Evaluation of Chlorpyrifos to Amphibian Chinese toad (Amphibian: Anura) by Comet Assay and Micronucleus Test. Mutation Research/Genetic Toxicology Environmental Mutagenesis, 680, 2-6. http://dx.doi.org/10.1016/j.mrgentox.2009.05.018

[15] Olive, P.L., Banáth, J.P. and Durand, R.E. (1990) Heterogeneity in Radiation-Induced DNA Damage and Repair in Tumor and Normal Cells Measured Using the “Comet” Assay. Radiation Research, 122, 86-94. http://dx.doi.org/10.2307/3577587

[16] Gedik, C., Ewen, S. and Collins, A. (1992) Single-Cell Gel Electrophoresis Applied to the Analysis of UV-C Damage and Its Repair in Human Cells. International Journal of Radiation Biology, 62, 313-320. http://dx.doi.org/10.1080/09553009214552161

[17] OECD (Organization for Economic Co-Operation and Development) (1992) OECD Guideline for Testing of Chemicals. Fish, Acute Toxicity Test, 203, 1-9.

[18] TSK (Trimmed Spearman-Karber) Program (1991) Version 1.5. Ecological Monitoring Research Division, Environmental Monitoring Systems Laboratory, US Environmental Protection Agency, Cincinnati.

[19] Singh, N.P., McCoy, M.T., Tice, R.R. and Schneider, E.L. (1988) A Simple Technique for Quantitation of Low Levels of DNA Damage in Individual Cells. Experimental Cell Research, 175, 184-191. http://dx.doi.org/10.1016/0014-4827(88)90265-0

[20] Anderson, D., Yu, T.W., Phillips, B. and Schmezer, P. (1994) The Effect of Various Antioxidants and Other Modifying Agents on Oxygen-Radical-Generated DNA Damage in Human Lymphocytes in the COMET Assay. Mutation Research/Fundamental and Molecular Mechanisms of Mutagenesis, 307, 261-271.

[21] Grover, P., Danadevi, K., Mahboob, M., Rozati, R., Banu, B.S. and Rahman, M. (2003) Evaluation of Genetic Damage in Workers Employed in Pesticide Production Utilizing the Comet Assay. Mutagenesis, 18, 201-205. http://dx.doi.org/10.1093/mutage/18.2.201

[22] US Environmental Protection Agency (2002) Methods for Measuring the Acute Toxicity of Effluents and Receiving Waters to Freshwater and Marine Organisms. EPA-821-R-02-012. Office of Water, Washington DC.

[23] Ralph, S. and Petras, M. (1998) Comparison of Sensitivity to Methyl Methanesulphonate among Tadpole Developmental Stages Using the Alkaline Single-Cell Gel Electrophoresis (Comet) Assay. Environmental and Molecular Mutagenesis, 31, 374-382. http://dx.doi.org/10.1002/(SICI)1098-2280(1998)31:4<374::AID-EM10>3.0.CO;2-9

[24] Richards, S.M. and Kendall, R.J. (2002) Biochemical Effects of Chlorpyrifos on Two Developmental Stages of Xenopus laevis. Environmental Toxicology and Chemistry, 21, 1826-1835. http://dx.doi.org/10.1002/etc.5620210910

[25] Pan, D. and Liang, X. (1993) Safety Study of Pesticides on Bog Frog, a Predatory Natural Enemy of Pest in Paddy Field. Journal of Hunan Agricultural College, 19.

[26] Fairbairn, D.W., Olive, P.L. and O’Neill, K.L. (1995) The Comet Assay: A Comprehensive Review. Mutation Research/Reviews Genetic Toxicology, 339, 37-59. http://dx.doi.org/10.1016/0165-1110(94)00013-3

[27] Pavlica, M., Klobucar, G., Mojas, N., Erben, R. and Papes, D. (2001) Detection of DNA Damage in Haemocytes of Zebra Mussel Using Comet Assay. Mutation Research/Genetic Toxicology and Environmental Mutagenesis, 490, 209-214. http://dx.doi.org/10.1016/S1383-5718(00)00162-5

[28] Steinert, S.A. (1999) DNA Damage as a Bivalve Biomarker. Biomarkers, 4, 492-496. 
http://dx.doi.org/10.1080/135475099230651

[29] Gollapudi, B.B., Mendrala, A.L. and Ann Linscombe, V. (1995) Evaluation of the Genetic Toxicity of the Organophosphate Insecticide Chlorpyrifos. Mutation Research/Genetic Toxicology, 342, 25-36.

[30] Clements, C., Ralph, S. and Petras, M. (1997) Genotoxicity of Select Herbicides in Rana catesbeiana Tadpoles Using the Alkaline Single-Cell Gel DNA Electrophoresis (Comet) Assay. Environmental and Molecular Mutagenesis, 29, 277-288. http://dx.doi.org/10.1002/(SICI)1098-2280(1997)29:3<277::AID-EM8>3.0.CO;2-9

[31] Feng, S., Kong, Z., Wang, X., Zhao, L. and Peng, P. (2004) Acute Toxicity and Genotoxicity of Two Novel Pesticides on Amphibian, Rana N. Hallowell. Chemosphere, 56, 457-463. http://dx.doi.org/10.1016/j.chemosphere.2004.02.010

[32] Mouchet, F., Gauthier, L., Mailhes, C., Ferrier, V. and Devaux, A. (2006) Comparative Evaluation of Genotoxicity of Captan in Amphibian Larvae (Xenopus laevis and Pleurodeles waltl) Using the Comet Assay and the Micronucleus Test. Environmental Toxicology, 21, 264-277. http://dx.doi.org/10.1002/tox.20180

[33] Yin, X.H., Li, S.N., Zhang, L., Zhu, G.N. and Zhuang, H.S. (2008) Evaluation of DNA Damage in Chinese Toad (Bufo bufo gargarizans) after in Vivo Exposure to Sublethal Concentrations of Four Herbicides Using the Comet Assay. Ecotoxicology, 17, 280-286. http://dx.doi.org/10.1007/s10646-008-0195-z 